\title{
Caso Avá-Guarani e a UHE Itaipu Binacional sob os olhares da Justiça de Transição
}

JÚLLA C. CARVALHO NAVARRA

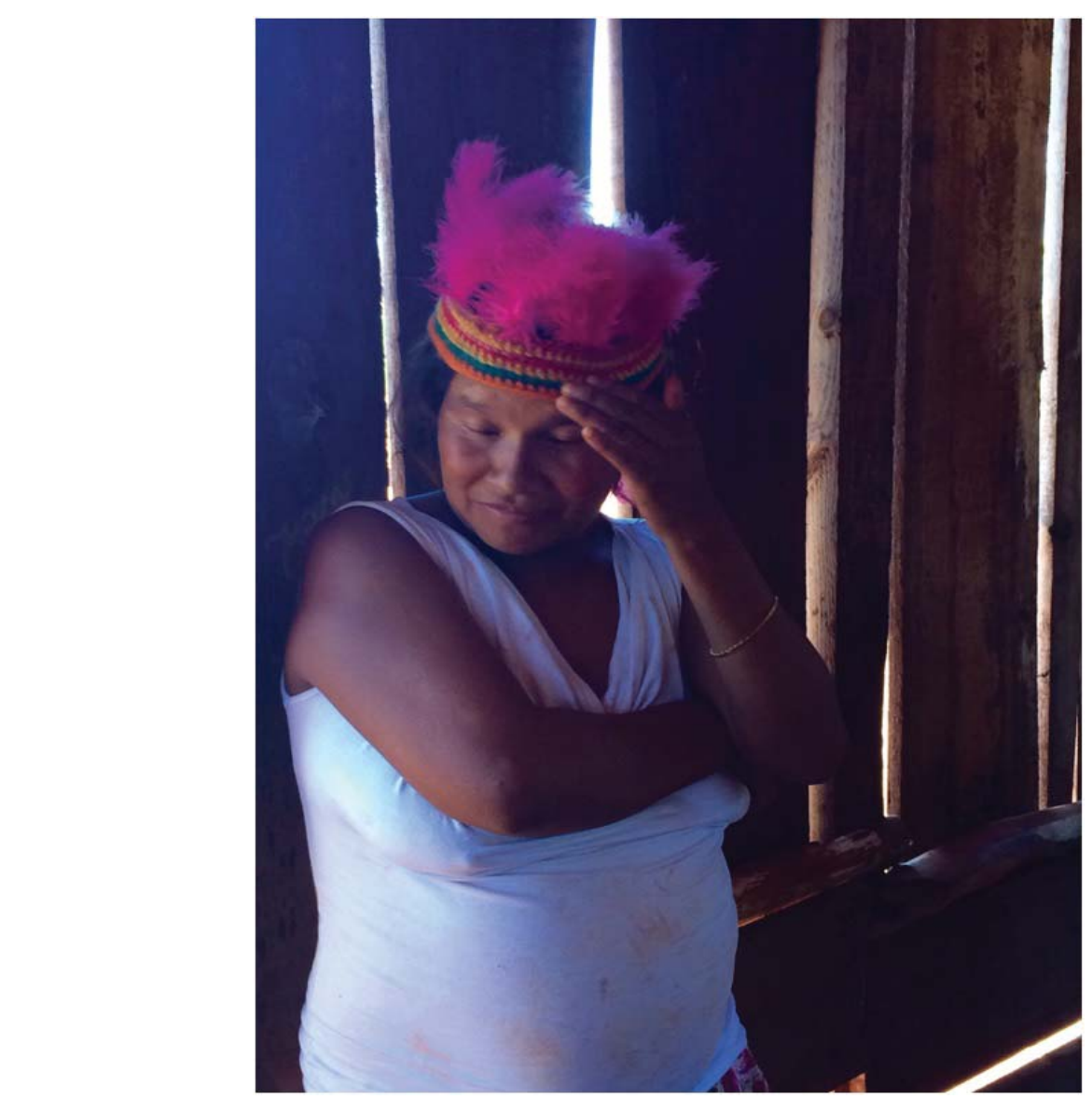

Imagem 1: Liderança Avá-Guarani da Tekoha Tatury, Guaíra (PR). Foto: Júlia Carvalho Navarra, Centro de Trabalho Indigenista, 2016.

Advinda do período de 1980 a 1990, a Justiça de Transição, de forma introdutória, pode caracterizar-se por um conjunto de medidas políticas, sociais e judiciais utilizadas como forma reparatória de violações de Direitos Humanos. Tal mecanismo veio como resposta às mudanças políticas vividas pós governos autoritários na América Latina e na Europa Oriental. 
Nesse sentido, é importante ter em mente que a própria construção da Justiça Transicional é um modo de colocar em xeque o conceito em disputa de "Justiça", desapegando-se de uma mera leitura punitivista do termo. Entenda-se que a responsabilização dos agressores (responsabilização e punição) faz parte do escopo de medidas a garantir justiça às vítimas, mas o foco centra-se em trabalhar o direito à reparação - algo bem mais abrangente e complexo. A reconstrução de certas narrativas históricas, a garantia à verdade e a memória, o fortalecimento das instituições democráticas. Tudo isso, por exemplo, enquadra-se no entendimento de reparação. A pessoa/grupo que sofre ou sofreu as violações apuradas passa a ter papel fundamental na decisão das medidas a serem demandadas do agressor.

Assim, entendendo a reparação como um processo político junto a comunidades e indivíduos afetados, pode-se dizer que ela extrapola o universo administrativo e jurisdicional, desenhado-se em função das violações sofridas e, portanto, apresenta aspectos de natureza subjetiva - ainda mais em se tratando de violações de povos indígenas, que envolvem aspectos materiais a cosmológicos muito específicos. Compreender o sentido, a natureza e a extensão das violações sofridas sob a perspectiva da própria vítima faz do trabalho da/o antropóloga/o ainda mais importante, na qualificação etnográfica a tentar entender todas as nuances acerca das violações cometidas nestes casos.

Exemplos de medidas reparatórias a povos indígenas podem ser extraídas das próprias recomendações da Comissão Nacional da Verdade, em seu capítulo indígena. Dentre os apontamentos encontramos diversas ações como a conclusão de processos de identificação, demarcação, delimitação e homologação; a elaboração de políticas públicas de fortalecimento cultural; o reconhecimento público de responsabilização pelo Estado ou mesmo a divulgação ampla dos materiais produzidos no período ditatorial.

Dentro do escopo de tais atividades, cabe ao Ministério Público encampar os procedimentos de reparação a partir de análises mais aprofundadas, envolvendo um estudo multidisciplinar a embasar estes processos. É em meio a esta competência que se criou, em 2013, o Grupo de Trabalho específico de Justiça de Transição - sobre violações dos direitos dos povos indígenas e o Regime Militar.

Muitos foram os casos levantados pelo GT, abarcando uma diversidade de povos indígenas atingidos, dentre eles: dos Tenharim (AM) frente à Transamazônica, dos Waimiri-Atroari (AM) com a Rodovia BR-174, do Reformatório Krenak (MG) ou do povo Xavante (MG) por conta dos deslocamentos forçados.

No entanto, cabe aqui destacar o caso que nos interessa na presente análise: as violações cometidas em face do povo Avá-Guarani (PR) por conta da construção da Usina Hidrelétrica de Itaipu Binacional. 


\section{Sobre o Oeste do Paraná e o povo Avá-Guarani ou Nhandeva}

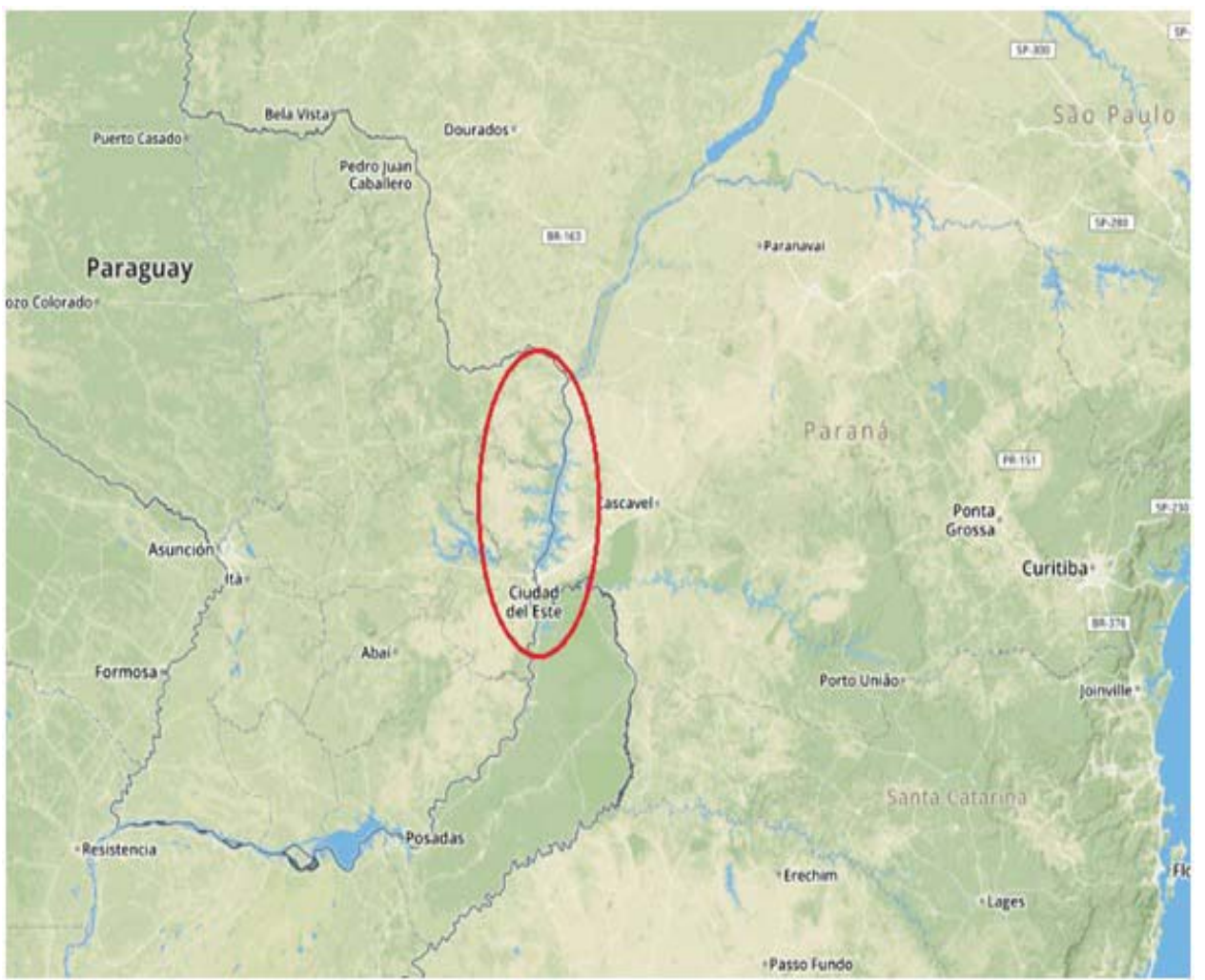

Imagem 2:"Mapa com recorte na região da Bacia Platina, região que abarca as 25 ocupações Avá-Guarani elencadas anteriormente, a segunda maior bacia hidrográfica do país, com cerca de $60 \%$ do aproveitamento hidrelétrico advindo da região." - print de região selecionada no Google Maps.

Mesmo sendo a maior população indígena da América Latina, os Guarani seguem tendo um número ínfimo de terras homologadas, o menor, proporcionalmente, em detrimento dos demais povos. O Oeste do Paraná é apenas um reflexo deste quadro em escala nacional.

Contendo uma população que soma aproximadamente mais de 2 mil indígenas, os Avá-Guarani da região abrangida se distribuem, em cerca de 25 Tekohas (aldeias) ao todo - quatorze localizadas em Guaíra e Terra Roxa; cinco em Santa Helena; duas em Itaipulândia, uma em São Miguel do Iguaçu e duas em Diamante D'Oeste. ${ }^{1}$

1 https://guarani.map.as/\#!/ - Mapa Guarani Digital. 


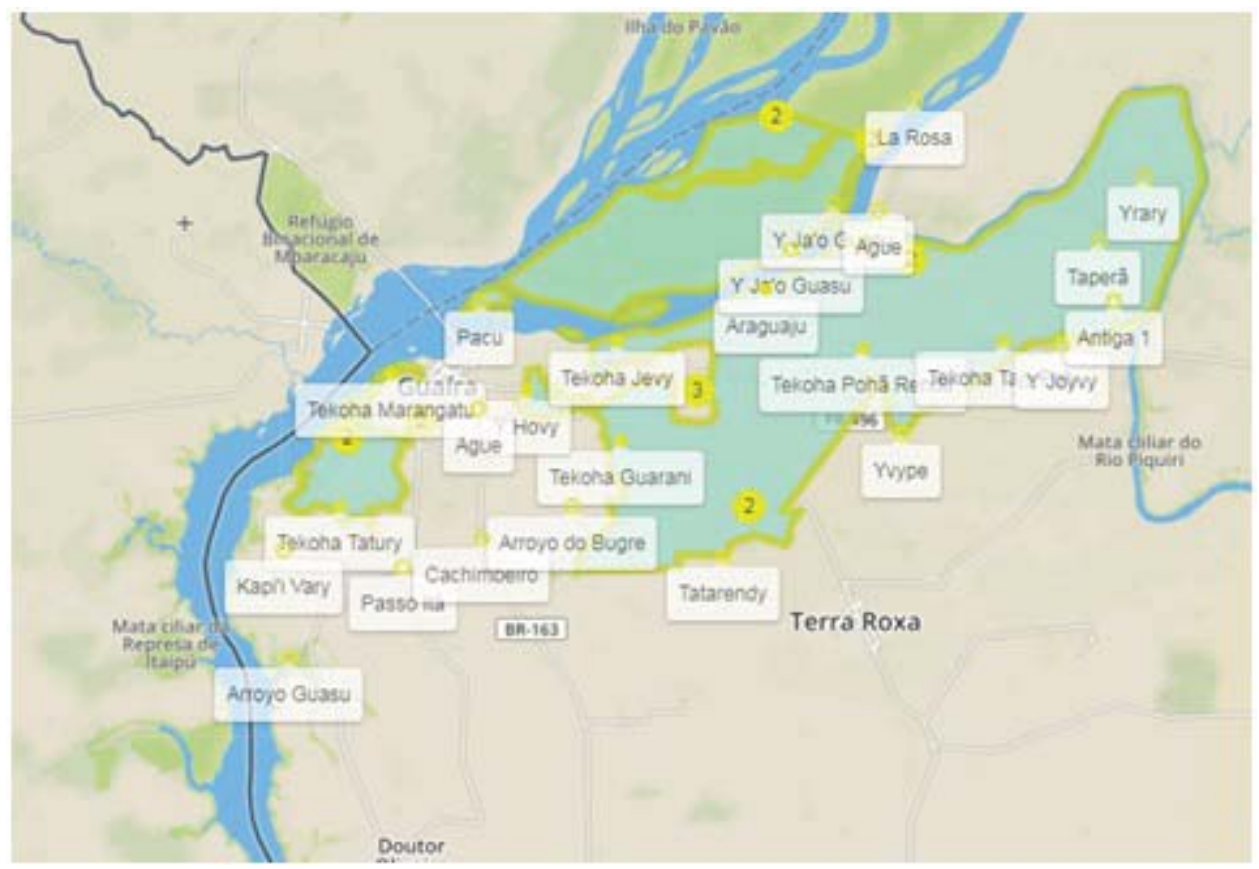

Imagem 3: Guaíra e Terra Roxa (PR)

Informações extraídas do site: https://guarani.map.as/, plataforma colaborativa que reúne a localização georreferenciadas de todas as ocupações Guarani no país, atuais e antigas, ademais dos sítios arqueológicos.

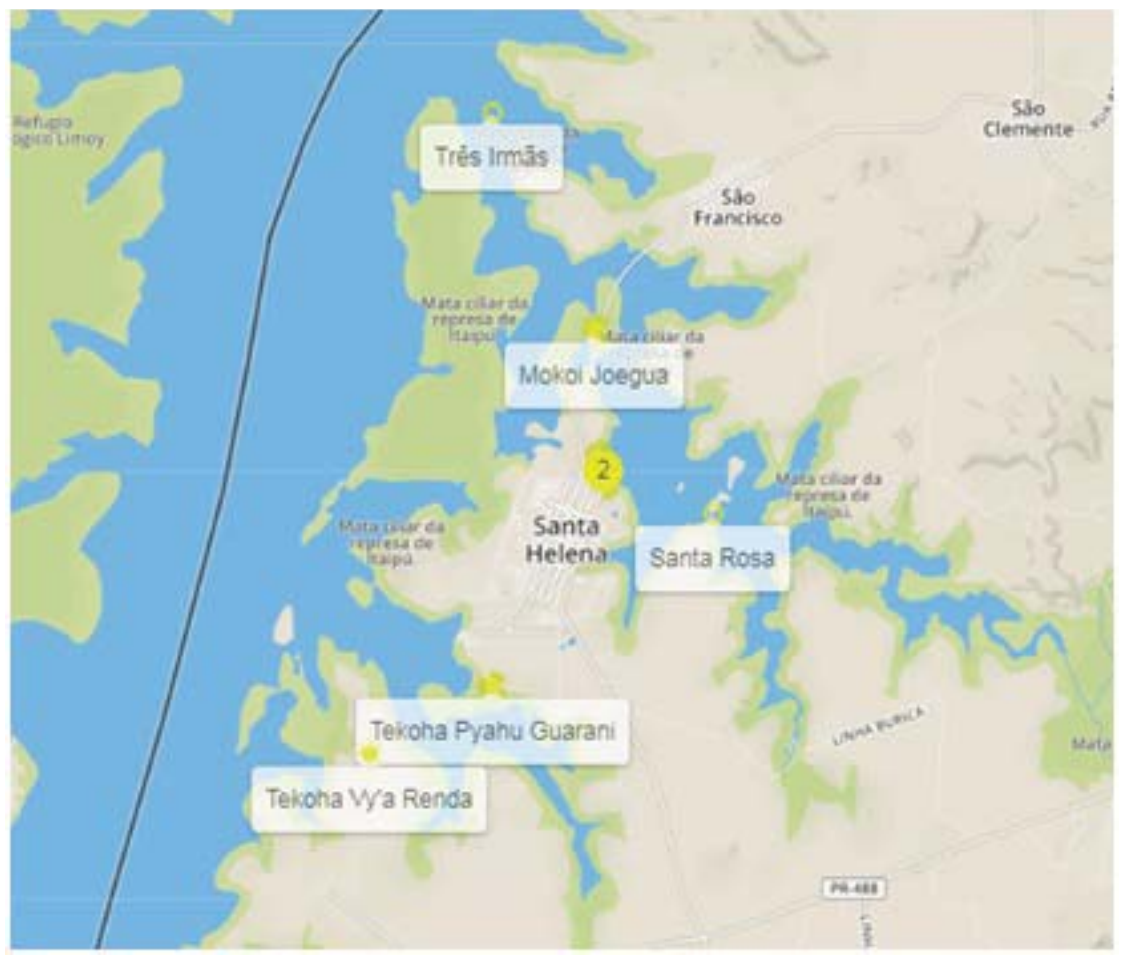

Imagem 4. Santa Helena (PR) 


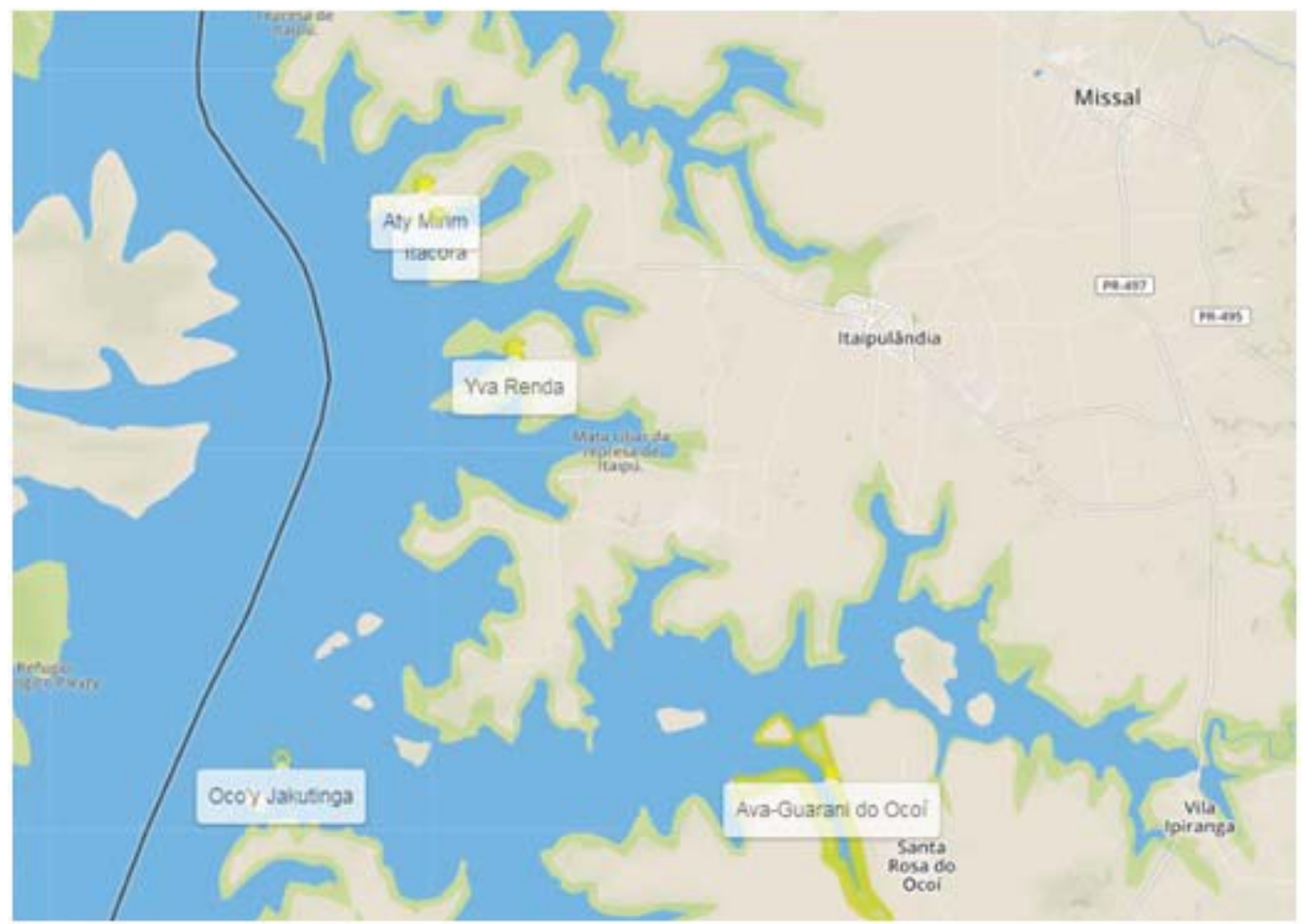

Imagem 5: Itaipulândia e Santa Rosa do Ocoí (PR)

\section{A Colonização no Oeste paranaense e o esbulho dos Avá- Guarani}

Historicamente, a região da Bacia Platina, que compreende a Tríplice Fronteira entre Brasil, Paraguai e Argentina, foi sempre ocupada pelo povo Avá-Guarani. Com uma apropriação fluida e dinâmica do espaço, os guarani tradicionalmente estiveram presentes na região fronteiriça, dada a intensa mobilidade social em função das redes de parentesco. Mesmo levando-se em consideração os fluxos migratórios transfronteiriços, o Oeste paranaense apresentava, desde os primórdios da invasão portuguesa, uma numerosa concentração de aldeamentos.

De acordo com os dados sistematizados pela Comissão Estadual da Verdade do Paraná2, os primeiros relatos de violências contra os guaranis na área (dos quais se tem registro) remontam quase 500 anos - entre 1540 a 1545. O militar espanhol Alvar Núñez Cabeza de Vaca visitou a América Latina nesse período e retratou a presença da etnia no local.

"A bandeira de 1628 iniciou suas atividades com certa cautela, com Raposo Tavares estabelecendo um arraial às margens do Tibagi, na entrada do território do Guairá. A partir desta base, os paulistas começaram, com o fim de fazer cativos, a assaltar aldeias guarani, logo apelando para as reduções. Tal objetivo foi atingido através da violência nua e crua. Segundo o relato de um jesuíta, o método usual dos paulistas consistia em cercar a aldeia e persuadir seus habitantes, usando de força ou de ameaças, a acompanhar os colonos de volta para São Paulo. Um destino terrível reservava-se às aldeias que ousassem resistir. (...) Até 1632, as sucessivas invasões haviam destruído boa parte das aldeias guarani e virtualmente todas as reduções do Guairá. Desta forma, milhares de cativos guarani foram introduzidos em São Paulo" (Monteiro 1994).

2 Lei 17362 - 27 de Novembro de 2012 - Comissão Estadual da Verdade do Estado do Paraná. 
Em meio a colonização, dado o acesso relativamente fácil e estratégico militarmente, a região fronteiriça foi tornando-se um ponto de encontro das expedições coloniais portuguesas e espanholas (Monteiro 1994). Nesse contexto, de acordo com o antropólogo e etnólogo espanhol, Bartomeu Melià, o território ocupado pelos Avá-Guarani vem a fortalecer-se como pólo de interesse dos colonizadores também por conta do trabalho da erva-mate, ganhando um considerável valor na economia colonial paraguaia: "A partir daí, os Avá foram atraídos e aliciados para um trabalho quase escravo num sistema de exploração grande, de cruel discriminação e muito sofrimento" (Meliá 2016).

Já nos anos de 1940, a campanha getulista da "Marcha para o Oeste" despendeu esforços em uma grande missão colonizadora a "ocupar" um suposto vazio demográfico. A mesma narrativa que seria utilizada na região Amazônica no período da Ditadura Militar. De acordo com o Relatório Figueiredo 3 - documento essencial a servir de base ao capítulo indígena da Comissão Nacional da Verdade - o governo atuou em várias frentes de modo a promover a incorporação das terras fronteiriças ao território nacional. Sob a égide da política federal, contatava-se as populações indígenas isoladas, favorecendo a invasão e titulação dos territórios a terceiros.

Entre os anos 1930 e 1960, especificamente no estado do Paraná, muitas ocupações indígenas foram tituladas para empresas de colonização e particulares. Vale ressaltar que em meio a este processo notabiliza-se a atuação do governo de Moysés Lupion (CNV 20:: 206), que, de 1947 a 1951, não poupou esforços no sentido de apropriar-se dos territórios indígenas, considerando-os como "terras devolutas" por meio de uma aparelhada articulação dos órgãos públicos competentes na época. Foi nesse processo de aceleração de concessões de terra por parte do Estado, no fim da década de 194, para fins de colonização que a Serra dos Dourados ocupada até então pelos Xetá foi devastada por agrimensores e topógrafos do DGTC - Departamento de Geográfica, Terras e Colonização (Mota 2017).

Em meio a clara diretriz colonizadora a orientar a atuação pública não apenas no âmbito estadual como federal, a Superintendência Regional do Instituto Nacional de Colonização de Reforma Agrária no Paraná atua fortemente na implementação dos chamados Projetos Integrados de Colonização (PIC). Com um enorme esforço em acelerar o desenvolvimento econômico brasileiro, os PICs seguiam a mesma orientação colonizadora que entendia que as regiões ocupadas por populações tradicionais eram, em realidade, um grande vazio demográfico.

Assim, durante a década de 1970, em meio ao PIC do Paraná em Ocoí, a inauguração do Parque Nacional do Iguaçu (Lei ${ }^{\circ}$ 1035/39) consolida a expulsão de diversas aldeias e de pequenos proprietários rurais da região. Por conta dele, 12 mil hectare de terras consideradas devolutas foram tomadas e usadas para reassentamento de colonos desapropriados do Parque Nacional do Iguaçu. Nesse meandro, o instituto, a fim de evitar a necessidade de ressarcimento pela desapropriação, considerava os guaranis como "mestiços" ou paraguaios, atuando notoriamente em desfavor dessas comunidades.

Anos depois, menos de uma dezena de famílias indígenas conseguiu receber títulos de terra. Em 2005, parte da comunidade esbulhada tenta o reingresso na área e, posteriormente, em 2013, sendo

3 Relatório Figueiredo. 30 Volumes. Disponível em Acervo online do Museu do Índio: http://museudoindio.gov.br/divulgacao/noticias/225-museu-do-indio-organiza-e-disponibiliza-relatorio-figueiredo. 
removidos em 2014 do parque por meio de mais de uma reintegração de posse peticionadas pelo Instituto Chico Mendes de Biodiversidade (ICMBio) e o próprio Ministério Públicó4.

\section{Sobre a UHE Itaipu Binacional - um capítulo à parte}

O último grande movimento de um processo que, ao longo de séculos, pressionou os indígenas para fora do Estado e do país, a construção da Usina Hidrelétrica de Itaipu Binacional remonta um processo violento de drástica interferência na paisagem, nos espaços e nos recursos da região a dar suporte para a sobrevivência física e cultural do povo Avá-Guarani.

Nos anos 1970, a UHE, projetada em 1971 e colocada em funcionamento em 1983, alagou um território de cerca de 135 mil ha, abrangendo outros 15 municípios além de Foz do Iguaçu. O maior projeto hidrelétrico do mundo até então, não contou, no entanto, com a consulta, informação ou sequer um plano mínimo de realocação das comunidades afetadas. A Comissão Nacional e Estadual da Verdade registra que ao menos 32 aldeamentos que ficaram completamente submersos ${ }^{5}$, alguns deles nos quais as pessoas só descobriram que teriam que sair quando viram a água subindo repentinamente.

De acordo com a coordenadora do capítulo indígena da CNV, Maria Rita Kehl, o componente indígena que trataria da mitigação dos impactos da obra aparecia inicialmente como "uma coisa pequena, uma nota de rodapé”. Embora já existisse legalmente a necessidade de realização prévia de estudos de impactos ambientais para grandes empreendimentos desde 1965, Itaipu se viu livre de todas as condições impostas por um licenciamento. A sua relevância estratégica para o regime militar isentou a obra das responsabilidades civis,ambientais e penais. Segundo relatos dos próprios Avá-Guarani, muitos foram expulsos sem qualquer tipo de consulta ou reparação, mediante ameaças, violências físicas e psicológicas, incêndios das suas casas, inundando a maior cachoeira do mundo em volume de água, as Sete Quedas, cujo valor cosmológico e espiritual para os indígenas da região fez com que muitos preferissem morrer ao viver sem o legado de Nhanderu (deus) ${ }^{6}$.

"O que nós vamos fazer? Itaipu disse 'pode sair tudo'. Eu fui, tenho quatro filhos... Choramos tudo, vai pra Paraguai, vai pra não sei onde [...] Nós morávamos na terra [...] Mas fazer o quê? Naquele tempo manda o Exército, né? Naquele tempo não existia lei, nada” Lourenço Figueiredo, cacique da aldeia Dois Irmãos, para a Comissão Nacional da Verdade

"Itaipu está devendo para os índios milhares de terras. Ele destruiu a nossa vivência. Não adianta a prefeitura e nem Itaipu dizer para nós 'vamos tirar esse índio daqui e levar para longe'. Não. Não vai de jeito nenhum. Isso não vai acontecer. Para acabar essa briga tem que ajuntar todos os índios e metralhar, matar todos os índios para acabar com a dor de cabeça para o branco, para o fazendeiro e para Itaipu também. Enquanto vivermos sempre vamos seguir a luta. Se eu morrer, tem o meu filho que vai continuar." [Ismael Martins, Avá-Guarani da Tekoha Karumbe’y, Guaíra-PR]

4 ACP n 500587009.2012.4.04.7.004/ $2^{\circ}$ Vara Umuarama juiz Sandro Nunes Vieira e Reintegração de Posse $n^{\circ} 5011701$ 10.2013.404.7002/1 ${ }^{\circ}$ Vara Foz do Iguaçu juiz Sergio Luis Ruivo Marques.

5 Dados in Maria Lucia Brant de Carvalho, Laudo pericial para a Comissão Estadual da Verdade do Paraná - "Das terras dos índios a índios sem terras. O Estado e os Guarani do Ocơy: violência, silêncio e luta”.

6 Entrevista com o historiador Clóvis Brighenti da UNILA, Matéria “Ecos de Itaipu” da jornalista Isabel Harari. In: revista Apública. Acesso 26/04/2019< https://apublica.org/2015/03/os-ecos-de-itaipu/>. 
Em 1975, um vereador de Foz do Iguaçu, Antônio Vanderli Moreira, enviou carta a Armando Falcão, então ministro da Justiça, denunciando as arbitrariedades cometidas pelo Incra. Ele citava casos de índios que foram "presos e espancados" e relatava que "alguns fugiram para o Paraguai".

Abaixo, seguem as fotos datadas de julho de 1981, concedidas à Comissão da Verdade do Paraná por um ex-funcionário da empresa, mas que não foram incluídas no relatório final ${ }^{7}$. Nelas, os servidores do chamado "setor de desapropriações" posam para a câmera enquanto ateiam fogo em casas Guarani para expulsá-los do local. O relatório traz depoimentos de ex-funcionários da Itaipu, indígenas que moravam no local na época, documentos levantados, informações públicas e estudos de pesquisadores.

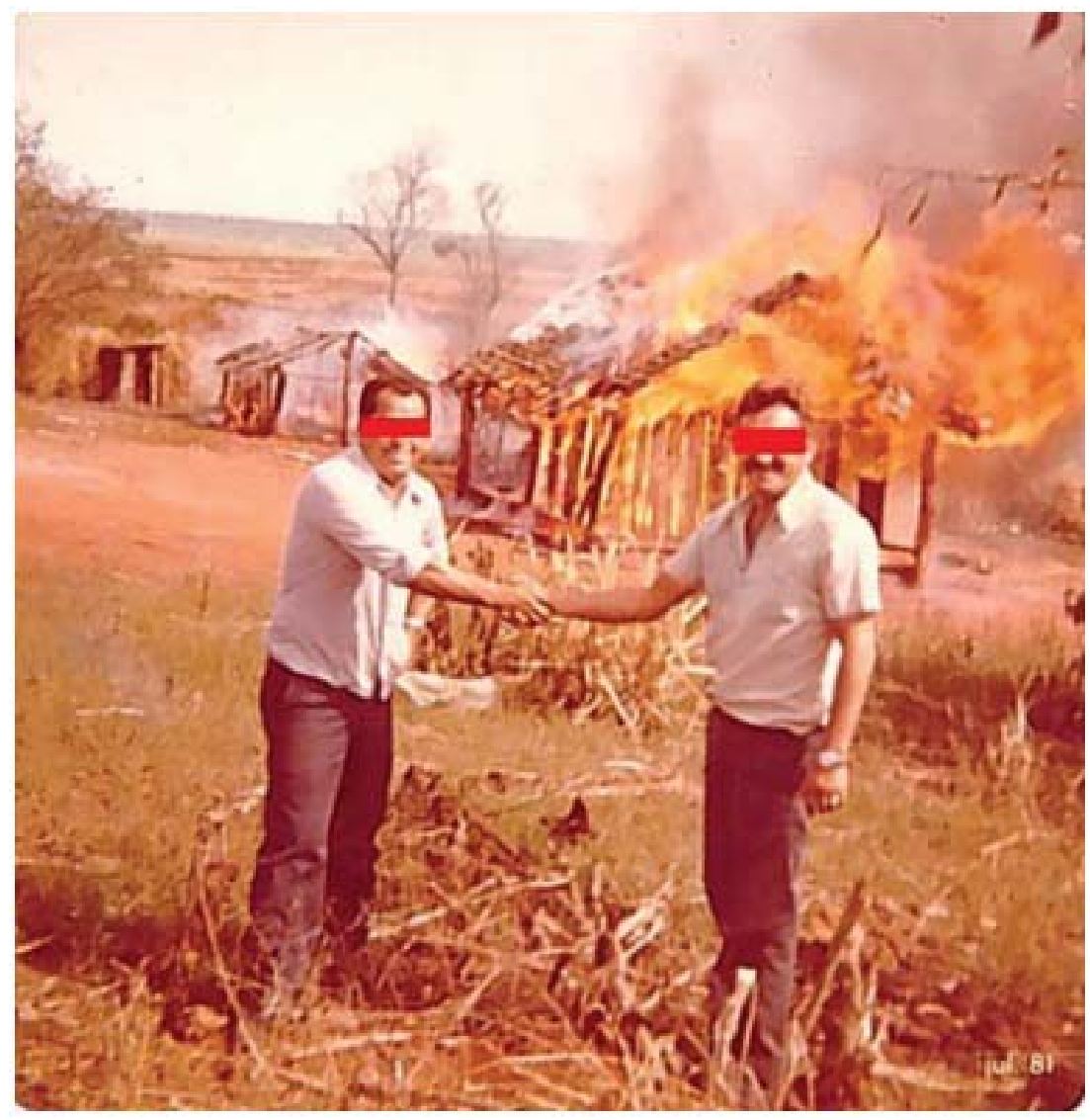

Imagem 6: Imagens foram entregues à Comissão da Verdade por um ex-funcionário de Itaipu, mas não foram incluídas no relatório final. Fotos: Acervo Comissão da Verdade do Paraná

7 AUDI, Amanda. “Fotos Inéditas: Funcionários de Itaipu Comemoram Incêndio em Casas Indígenas". 12 de junho de 2018, 2 h00. Ver em The Intercept Brasil https://theintercept.com/2018/06/12/fotos-funcionarios-itaipu-incendio-indigenas/. 

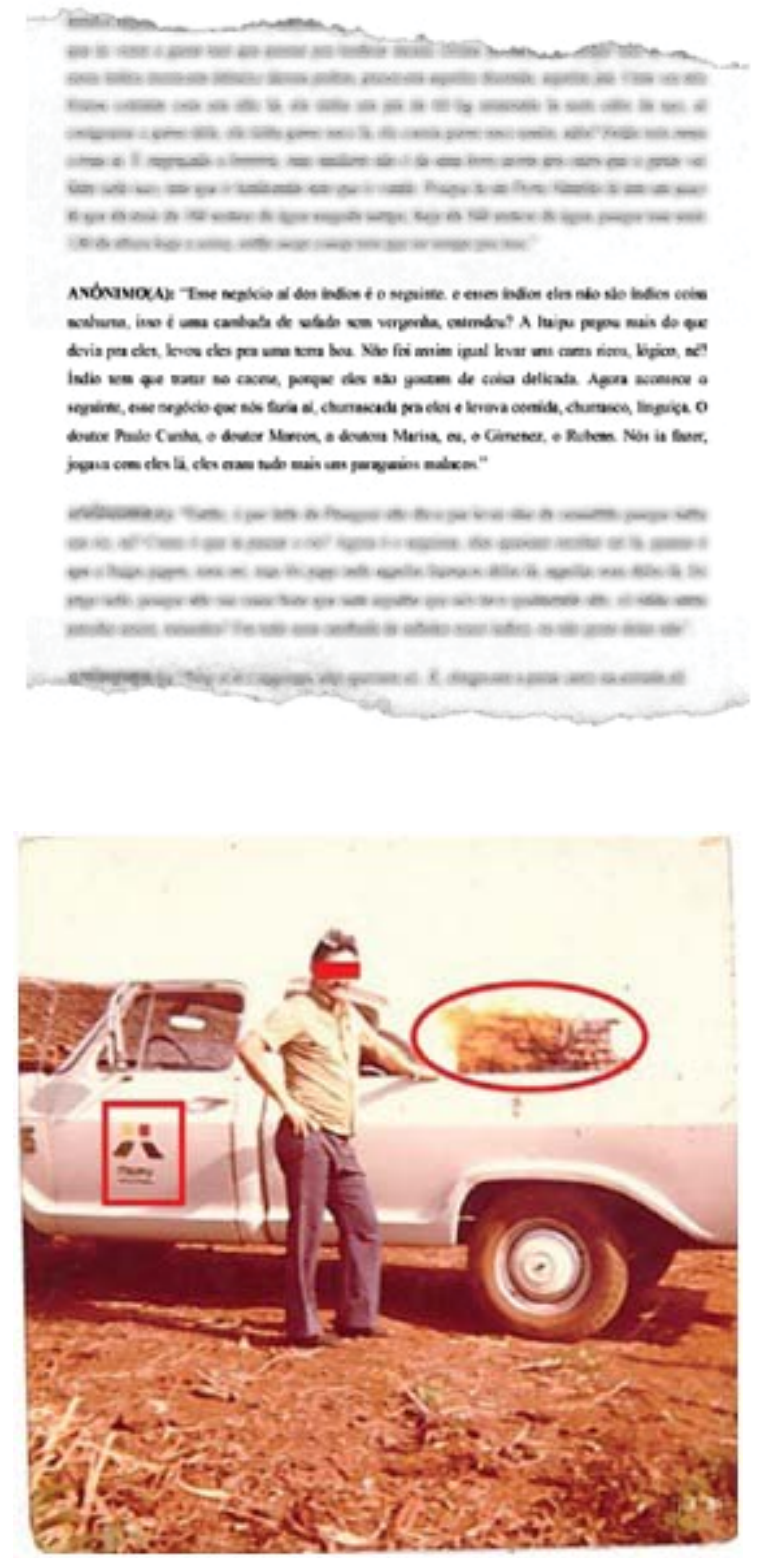

Imagens 7 e 8: Imagens foram entregues à Comissão da Verdade por um ex-funcionário de Itaipu, mas não foram incluídas no relatório final. Fotos: Acervo Comissão da Verdade do Paraná

Atualmente com 135 mil hectares inundados, a represa de Itaipu traz consigo um passado de cerca de 8 mil desapropriações (apenas no lado brasileiro), narra em seu depoimento ao Museu da Pessoa - SP o oficial do Exército Marius Vieira Gonçalves, chefe, na época, do setor de arquivos de desapropriações de Itaipu. De acordo com a CNV, foram removidas cerca de 42 mil pessoas da área. "Foram indenizados os que tinham título. O não reconhecimento foi a estratégia usada para praticar o esbulho", explica Diogo Oliveira, servidor da Funai que atuou na região entre 2012 e 2014.

"O Incra chega aqui, expulsando a gente da terra, eles assustavam a gente, ameaçavam, mandavam embora, botando fogo nas casas, queimando nossa plantação, atiravam nossas coisas na estrada [...] Ameaçavam dar tiro na perna em quem não "O Incra chega aqui, expulsando a gente da terra, eles assustavam a gente, ameaçavam, mandavam embora, botando fogo nas casas, queimando nossa plantação, atiravam nossas coisas na estrada [...] Ameaçavam dar tiro na perna em quem não queria subir no caminhão para o Paraguai", disse ex-morador em depoimento à Comissão da Verdade. 
Em relatos da comissão, fica claro que mesmo a Itaipu tinha consciência dos impactos e violências gerados aos povos indígenas. Um exemplo contundente é o memorando confidencial, de abril de 1987, assinado pelo diretor jurídico da empresa, Clóvis Ferro Costa:

"A minha convicção pessoal, hoje, é de que o pleito dos índios não é desarrazoado, de um lado; de outro, é evidente que o relatório sobre o qual se baseou Itaipu não é veraz. Digo isso em caráter confidencial, para evitar explorações judiciais e políticas [...] Dessa maneira, ao invés de Itaipu ter sido generosa, provavelmente terá subtraído muita área aos indígenas".
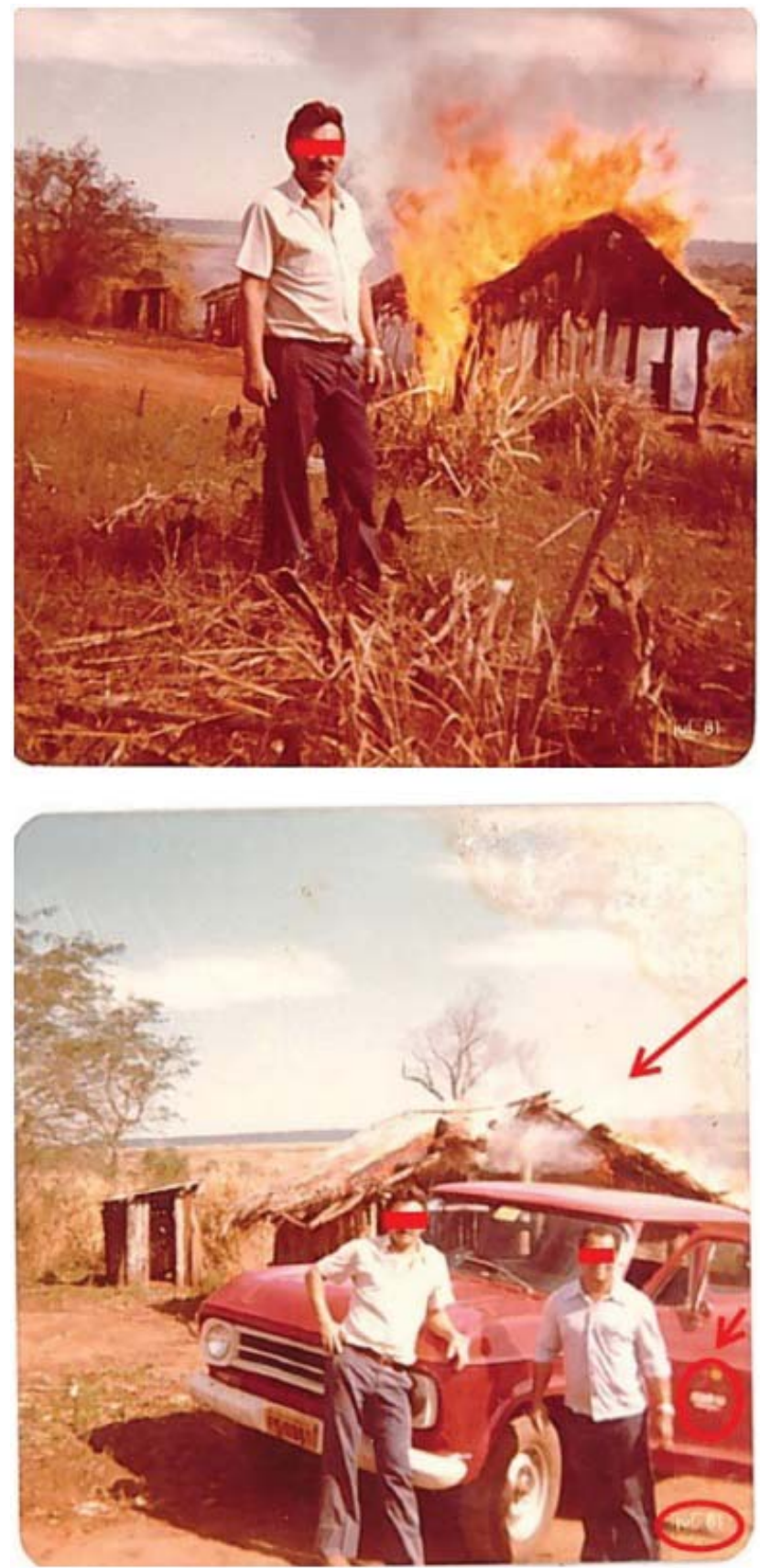

Imagens 9 e 10: Nas imagens disponibilizadas pelo ex-funcionário não identificado, dois membros da Itaipu Binacional posam após atear fogo nas casas de madeira atrás deles. É visível o logo da marca no carro da empresa.

8 ITAIPU BINACIONAL, Memorando interno I/JD.RJ/0052/87. Rio de Janeiro, abril de 1987. A Comissão Nacional da Verdade encaminhou ofício à UHE Itaipu no dia 2 de outubro de 2013 solicitando documentação referente à relação travada pela instituição com os Guarani do Paraná desde os anos 1970. A Comissão da Verdade nunca recebeu resposta e permanece sem acesso a essa documentação. 


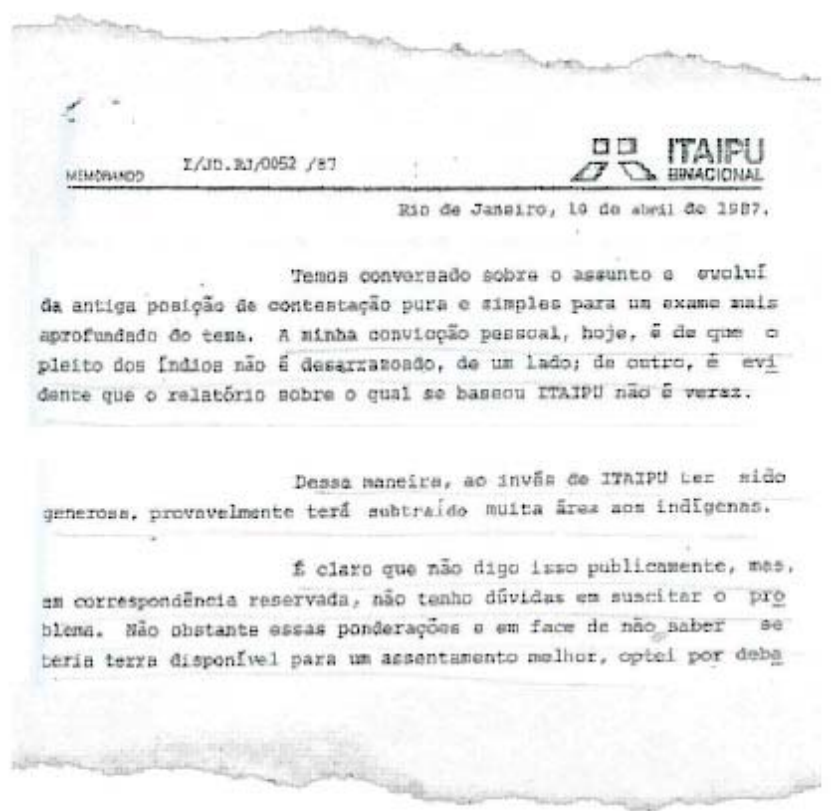

Imagem 11: Memorando interno de Itaipu Binacional, Rio de Janeiro, abril de 1987.

O ex-diretor-geral da UHE, Jorge Miguel Samek, que saiu o cargo em $2017^{9}$, já se posicionou de forma a considerar o Estado brasileiro responsável pela expulsão dos indígenas: "os índios já tinham sido expulsos antes [do levantamento de terras que seriam alagadas pela hidrelétrica]. A injustiça já tinha sido praticada em toda a região que compõe o território Guarani [...] Eu não sou hipócrita de achar que o que fizemos pagou a conta [pela expulsão dos Guarani]. A sociedade brasileira tem uma dívida impagável aí. Cada um tem que se esforçar para fazer a sua parte e eu me esforço muito para que Itaipu faça a sua parte”.

O caso é amplamente conhecido e fartamente documentado, tendo sido descrito mais detalhadamente por Relatório entregue à Comissão Nacional da Verdade:

O aproveitamento do potencial energético do rio Paraná e a possibilidade de se construir a hidrelétrica de Sete Quedas estava na agenda do Estado brasileiro desde os anos 1950, quando também se cogitou criar ali o Parque Nacional das Sete Quedas para abrigar o grupo indígena Xetá (cf. seção sobre desagregação social e extermínio). O empreendimento logo se tornou um assunto de grande interesse geopolítico e de segurança nacional quando o Paraguai, na época sob a ditadura de Alfredo Stroessner, também passou a fazer estudos na região. $\mathrm{O}$ acordo de parceria entre os dois países foi construído na Ata das Cataratas (1967) e no Tratado de Itaipu (1973). O projeto da usina previu a inundação de uma área de $1.350 \mathrm{~km} 2$ (cerca de 135 mil hectares), sendo 770 km2 do lado brasileiro, incidindo sobre os municípios de Foz do Iguaçu, Santa Helena, Marechal Cândido Rondon e Guaíra. As sucessivas fraudes cometidas pelos órgãos responsáveis pela situação dos índios e pela questão fundiária estão bem registradas para os territórios guarani de Foz do Iguaçu conhecidos como Ocoí-Jakutinga e Colônia Guarani, conforme documentação reunida no Setor de Documentação da Funai (processo 1.053/76). Esses territórios eram os últimos que haviam restado aos Guarani do oeste do Paraná como consequência do violento processo de esbulho sofrido nas décadas anteriores.

9 DOU n ${ }^{\circ}$ 50, terça-feira, 14 de março de 2017 - Exoneração. 
Ao longo de todo o processo, a Funai subordinou-se aos interesses do Incra e do IBDF sobre as terras ocupadas pelos índios, não aplicando a legislação indigenista em vigor num claro alinhamento à orientação do regime militar, aludida na introdução desse relatório, de não demarcar terras indígenas dentro da Faixa de Fronteira. A Funai permitiu assim que o Incra desenvolvesse dois projetos de colonização (PIC-Ocoí I e II) dentro do território guarani visando (i) assentar colonos que a partir de 1967 passaram a ser removidos do interior do Parque Nacional do Iguaçu (PNI) e (ii) definir a área que seria inundada pelo reservatório de Itaipu.

Em 1976, foi formado um primeiro GT entre Incra e Funai, em cujo relatório afirmava-se que na área do PIC-OCOI I, já totalmente invadida pelos colonos, não havia "qualquer resquício de elementos indígenas", e na área do PIC-OCOI II, existiam apenas 11 famílias guarani "em processo de aculturação". Na sequência do processo, formou-se novo GT, dessa vez entre a Funai e Itaipu, quando se procedeu à titulação individual da terra ocupada pelas famílias guarani, descaracterizando o direito indígena à terra e violando a legislação em vigor. Não bastou ao Estado, contudo, expulsar os Guarani de sua terra: buscou também negar sua identidade. Em 1981, Célio Horst, filho de criação de Ernesto Geisel, empunhando os "critérios de indianidade" que haviam sido elaborados pelo coronel Ivan Zanoni Hausen e introduzidos nos procedimentos fraudulentos da Funai a partir de 1979, produziu laudo em que reduziu o número de famílias guarani que teriam direito à terra de 11 para cinco. A situação se encaminhou em 1982 para a remoção e confinamento dos Guarani numa exígua faixa de terra à beira do lago de Itaipu, sem qualquer paridade em tamanho e condições ambientais com o território ocupado anteriormente, o que também violava a legislação indigenista vigente. Nesse local, a população guarani foi acometida por surtos de malária e doenças decorrentes do uso de agrotóxico pelos colonos vizinhos, surtos esses que dizimaram parte da população. Ao longo desse processo, a população guarani lutou intensamente contra essa supressão de direitos, recorrendo a advogados, antropólogos e ao próprio Banco Mundial (financiador da UHE Itaipu) para denunciar as sucessivas fraudes de que foi vítima e cobrar uma reparação justa ao prejuízo sofrido. Em um documento confidencial de Itaipu datado de 1987, Clóvis Ferro Costa, então diretor jurídico de Itaipu, afirmava: 'No dia 27 de março, promovi contato com representantes da comunidade Ava Guarani a fim de encaminhar uma solução possível para a pendência que instaurara contra nós. Temos conversado sobre o assunto e evoluí da antiga posição de contestação pura e simples para um exame mais aprofundado do tema. A minha convicção pessoal, hoje, é de que o pleito dos índios não é desarrazoado, de um lado; de outro, é evidente que o relatório sobre o qual se baseou Itaipu não é veraz. Digo isso em caráter confidencial, para evitar exploraçóes judiciais e políticas. Com efeito, os Ava-Guarani foram apresentados como tendo anteriormente apenas área em torno de 34 ha. E como Itaipu transferiu-lhes cerca de 250, a nossa postura teria sido generosa. Ocorre que o dado inicial é manifestamente incorreto, já pelos antecedentes de ocupação da área, já pelas informações coligidas. O próprio alegado nomadismo dos índios, contraposto com elementos em seu desfavor, induz à evidência de que não se reuniriam eles numa área tão pequena. Dessa maneira, ao invés de Itaipu ter sido generosa, provavelmente terá subtraído muita área aos indígenas. É claro que não digo isso publicamente, mas, em correspondência reservada, não tenho dúvidas em suscitar o problema.' Prevaleceu, contudo, a versão oficial dos "índios inexistentes" e da "generosidade de Itaipu", conforme pode ser verificado em documento oficial publicado por Itaipu em 1988. Para além das ilegalidades e fraudes cometidas contra os Guarani hoje em Ocoy, estão em jogo os procedimentos de Itaipu em relação a grupos da 
etnia que habitavam a margem do Paraná nos outros municípios da região (Santa Helena, Marechal Cândido Rondon, Guaíra), de onde também foram expulsos num processo ainda hoje pouco conhecido. Como testemunha o ancião Lourenço Figueiredo a respeito do território guarani Dois Irmãos, em Santa Helena: 'Aqui mesmo, em Dois Irmãos, tinha 70 famílias indígenas [...]. Eu era cacique também. Depois veio Itaipu e mandou tudo embora [...]. Falou que ia vir a água e que pode se mandar. E o que que nós ia fazer?! Naquele tempo o exército manda. Fazer o que né?! [...] Choremo tudo, vai pra Paraguai, vai pra não sei aonde.... [...] Foi em 1983 (sic)."' (Relatório da CNV, volume II, 2014, p. 218-220).

Em meio a um esbulho absoluto e sem o devido reconhecimento das violações praticadas nesse processo, a Itaipu "limpou a consciência" ao manter um dos 32 Tekohas (inundado parcialmente, digase de passagem) - a Reserva Indígena de Oco’y. Também denominada de RI Jacutinga, a reserva apenas permaneceu e abrigou algumas das famílias esbulhadas por conta da resistência dos próprio Guarani em sair da região. Apenas na véspera do fechamento das comportas, a Usina, FUNAI e INCRA resolveram considerá-los como camponeses, fazendo o registro individual dos lotes e indenizando parte das famílias. Mesmo assim, a maioria dos ocupantes decidiu que não queria dinheiro, mas compensação territorial.

Destarte, criou-se a reserva de Oco’y, localizada no município de São Miguel do Iguaçu, de 230 ha (originalmente 251 ha delimitados antes da inundação de parte do território), contendo, atualmente, cerca de 800 pessoas, espremidas entre monoculturas de soja e o lago formado pelo barramento da hidrelétrica. De acordo com o MPF de Foz do Iguaçu existe um inquérito civil aberto para apurar a situação de contaminação da aldeia por veneno utilizado nas fazendas próximas.

No início dos anos 80 e ainda hoje para algumas autoridades locais, Ocoy foi reconhecida como a única área indígena na região. No dia 31 de maio de 2016, o Grupo de Trabalho do Conselho Nacional de Direitos Humanos (CNDH) realiza uma visita in loco na Reserva Indígena de Ocoy e inclui o caso no Relatório de violação de direitos humanos por meio de sua Comissão Permanente temática. ${ }^{10}$

Também a $6^{\circ}$ Câmara de Coordenação e Revisão do Ministério Público Federal de Brasília lançou recentemente, no dia 25 de abril de 2019, o relatório Avá-Guarani: a construção de Itaipu e os direitos territoriais (Alcântara et alii 2019) comprovando as violações de direitos sofridas pela etnia em razão da construção da usina. O texto reúne documentos oficiais, depoimentos, pesquisa bibliográfica, fotografias e mapas a fim de mostrar que os Avá-Guarani foram deliberadamente excluídos dos processos de reassentamento e reparação, inclusive por órgãos do Estado, como a Funai e o Incra, e da própria Itaipu Binacional. $\mathrm{O}$ estudo, assim como o que se pretende neste documento,visa demonstrar como as consequências destes atos são vividas até os dias de hoje pelos guaranis.

Juntamente com o projeto desenvolvimentista do período ditatorial no país, a construção da hidrelétrica levou ao processo de Sarambi - como chamam os Guarani - de "esparramo" ou fuga das famílias para outras ocupações indígenas no estado, fora dele e, inclusive, em aldeias do Paraguai e Argentina. Ao longo desse processo, também há indícios de que o próprio órgão indigenista - extremamente militarizado na época - passou a registrar os indígenas como paraguaios, narrativa que infeliz-

10 CP, Resolução no 13, de 03 de dezembro de 2015. 
mente é sustentada até hoje, como forma de se evitar a responsabilização futura por conta das remoções forçadas e demais violações de direitos que delas decorreram.

\section{Resiliência e Luta - a resposta dos Avá e da Comissão Guarani Yvyrupa (CGY)}

Foram cometidas uma série de atrocidades por meio de ação e omissão do Estado, fomentando diversos atores públicos e privados a atuarem neste mesmo sentido. Com uma orientação política integracionista e colonizadora, não houve (e, infelizmente, ainda não há) espaço para outros modos de vida em solo nacional. $\mathrm{O}$ interesse público e privado sobre o território serviu de base a justificar uma série de graves violações de direitos humanos perpetradas contra os povos indígenas da região. Apenas considerando as violências documentadas pelos relatórios arrolados, os povos indígenas que viviam no Oeste paranaense sofreram por diversas práticas, tais como genocídios, envenenamentos, torturas, sequestros, apagamento cultural, contaminação dolosa por doenças, cárcere privado, trabalho escravo, remoções forçadas, incêndios de suas casas... Os Avá-Guarani, junto com outras etnias, trazem tristes relatos sobre esse período, havendo, inclusive, lembranças recentes de lideranças que tem na memória experiências vividas nesse passado.

Mesmo sendo o quinto país do mundo em extensão territorial ${ }^{11}$ e o mais extenso do hemisfério sul e da América Latina, o Brasil ainda carrega consigo as marcas de sua posição histórica de colônia, cuja intolerância e racismo geridos no seio da população unem-se a um modo de produção capitalista centrado em commodities e exportação de matérias primas de baixo valor agregado. É neste contexto que os cerca de $8.515 .767 \mathrm{~km}^{2}$ de extensão territorial do país parecem insuficientes diante da ganância do capital latifundiário.

Com base em um extenso compilado de documentação comprobatória, as Comissões Estadual e Nacional da Verdade, Relatórios Acadêmicos e, recentemente, do próprio Ministério Público Federal vieram à tona para confirmar esta narrativa. Por meio desses estudos é possível verificar a sistemática das violações cometidas e, em especial, alguns eventos traumáticos que geraram (e seguem gerando) graves impactos para a população indígena local. Em articulações com a 6a Câmara de Coordenação e Revisão, o Grupo de Trabalho do Ministério Público desenvolveu uma pesquisa histórica investigativa acerca da cadeia dominial do Oeste do Paraná, comprovando o processo de esbulho vivido pelos mais de 2 mil Avá Guarani do Oeste paranaense.

Em visitas de campo realizadas pelos procuradores e antropólogos da Procuradoria Geral da República, os dados levantados foram sistematizados em um relatório lançado em meio à Mobilização Nacional Indígena, em abril de 2019. O estudo intitulado "Avá-Guarani: a construção de Itaipu e os direitos territoriais" faz o esforço de comprovar as violações de Direitos Humanos sofridas pelos AváGuarani com a construção da Usina. Além de publicizar as violências cometidas pelo Estado e pela

11 Dados do IBGE de 2012. 
UHE, o trabalho busca balizar a instrução de Inquérito Civil ${ }^{12}$ da PGR a desembocar em judicialização em face dos responsáveis para demandar em juízo as medidas reparatórias adequadas ao caso.

Dentre as demandas trazidas pela comunidade ademais das reparações dos danos materiais, as lideranças pedem o reconhecimento territorial, programas de recuperação das áreas degradadas e a implementação de medidas a combater o preconceito sofrido por eles na região até hoje, reconstruindo a imagem dos índios perante os não-indígenas que vivem no local. Isso, pois além de terem perdido grande parte de seu território tradicional. o povo é alvo de campanhas difamatórias e investidas lideradas por grupos anti-indígenas, de agropecuaristas da região.

Nesse mesmo sentido, a própria comunidade vem se articulando politicamente no enfrentamento direto contra as mais de 39 ações de reintegrações de posse movidas contra as suas ocupações. Grandes latifundiários de monocultura de soja e milho (em sua maioria), a Matte Larangeira, o Estado do Paraná, a Usina de Itaipu - todos estes atores movem atualmente processos na justiça com a intenção de retirá-los de seus territórios. As justificativas são várias, mas em sua maioria giram em torno da construção de uma narrativa a deslegitimar a identidade do povo Guarani, afirmando que "não são índios de verdade" ou que são, em realidade, paraguaios, invasores de terras e, portanto, um entrave ao desenvolvimento econômico local. Isso é apenas um aspecto do discurso criado regionalmente a voltar a sociedade contra a permanência dos indígenas nestes espaços.

É neste contexto que a Comissão Guarani Yvyrrupa, organização indígena autônoma com lideranças de aldeias de todo Sul e Sudeste do Brasil, vem se articulando em resistência a essas investidas. Mais de 39 ações possessórias e nenhuma delas logrou retirá-los de suas ocupações tradicionais.

As comunidades Avá-Guarani de todo o Oeste do Paraná pleiteiam a demarcação de seus territórios: TI Guasu Guavirá, em Guaíra e Terra Roxa; e a TI Guasu Ocoy-Jacutinga, abrangendo os municípios de Santa Helena, Itaipulândia e São Miguel do Iguaçu. Com uma Funai sucateada, no entanto, os processos enfrentam muita resistência advinda especialmente do Poder Executivo sob o discurso inflamado anti-indígena do presidente Jair Bolsonaro.

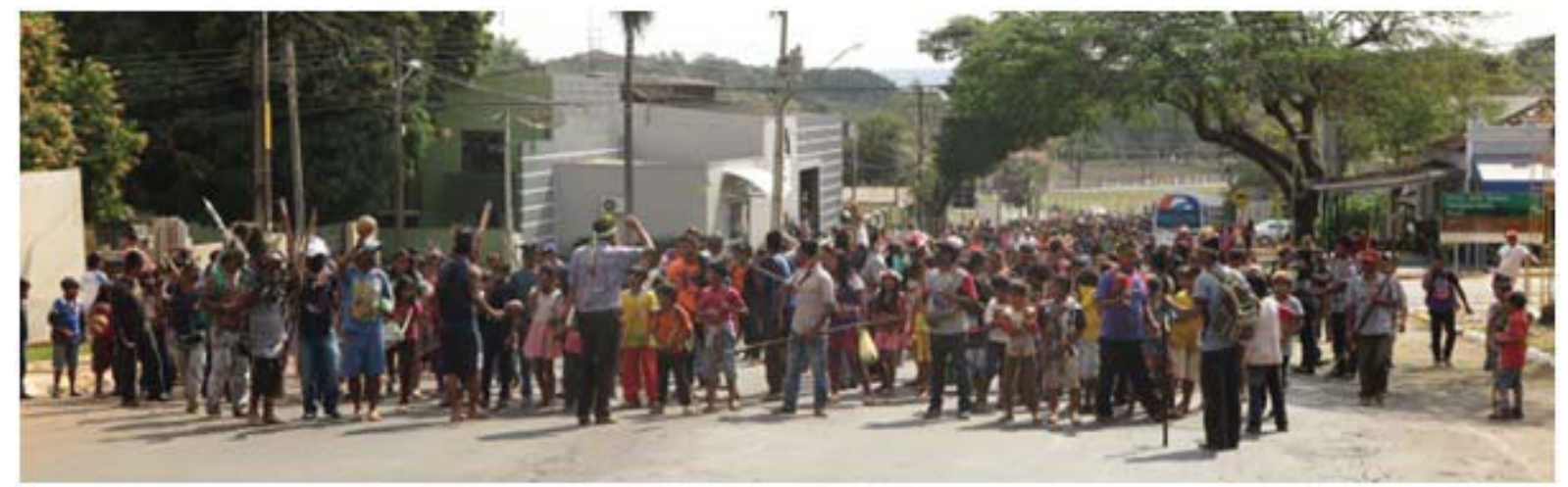

Imagem 12: Chegada da marcha ao centro de Guaíra. Foto: Comissão Guarani Yvyrupa (CGY), 2016.

Além disso, ao longo de 2016, a CGY reúne uma série de depoimentos dos indígenas que vivem nas delimitações dos municípios de Guaíra e Terra Roxa, elaborando um Relatório sobre Violações de

12 Inquérito Civil nº 1.25.003013674/2008-85. 
Direitos Humanos contra os Avá-Guarani do Oeste do Paraná ${ }^{13}$. No dia internacional dos Povos Indígenas, em agosto de 2017, os mais de 500 indígenas, juntamente com autoridades públicas e demais membros da sociedade civil organizada, saíram em marcha na cidade de Guaíra. No que foi a maior mobilização já realizada pelos Guarani na cidade, o relatório foi entregue em mãos ao prefeito, Heraldo Trento (DEM). ${ }^{14}$

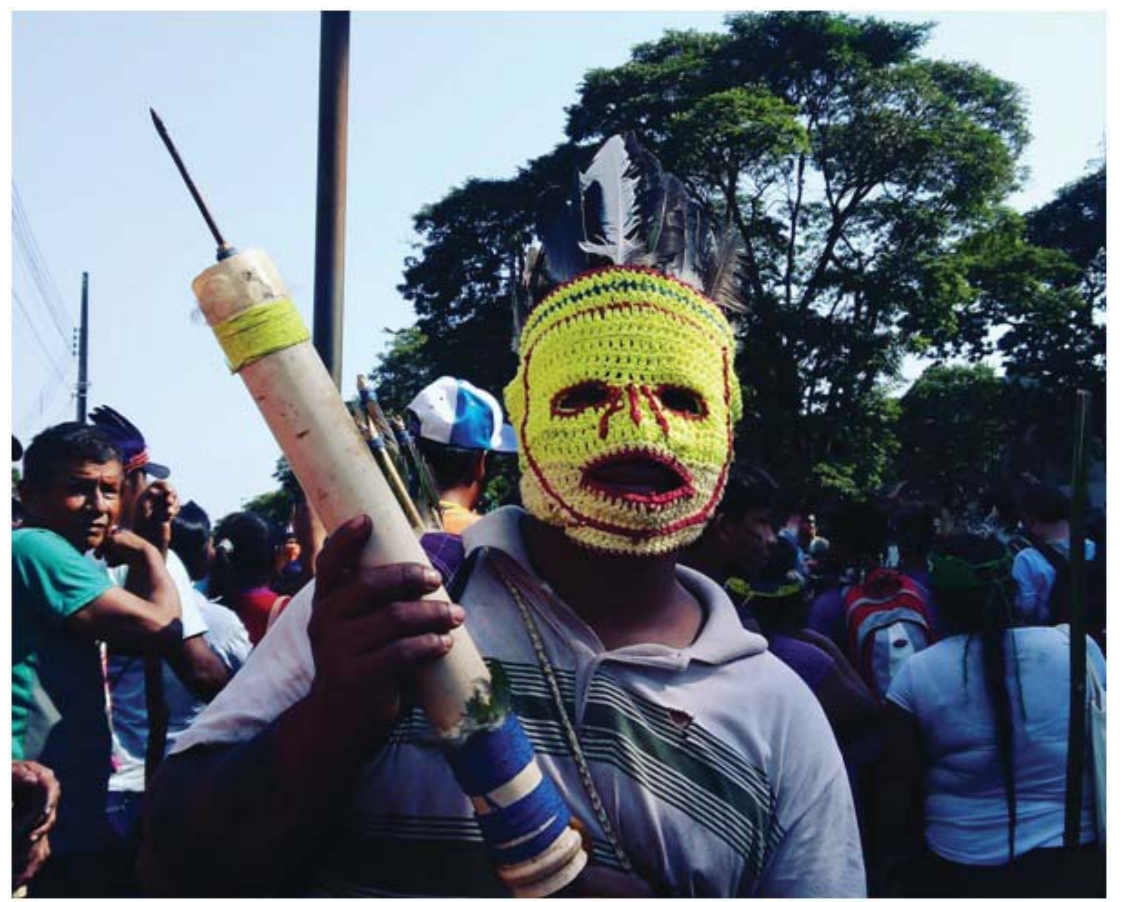

Imagem 13: Manifestante Avá- Guarani em marcha pela demarcação no centro da cidade de Guaíra (PR) em agosto de 2016. Foto de Júlia Carvalho Navarra, Centro de Trabalho Indigenista, 2016.

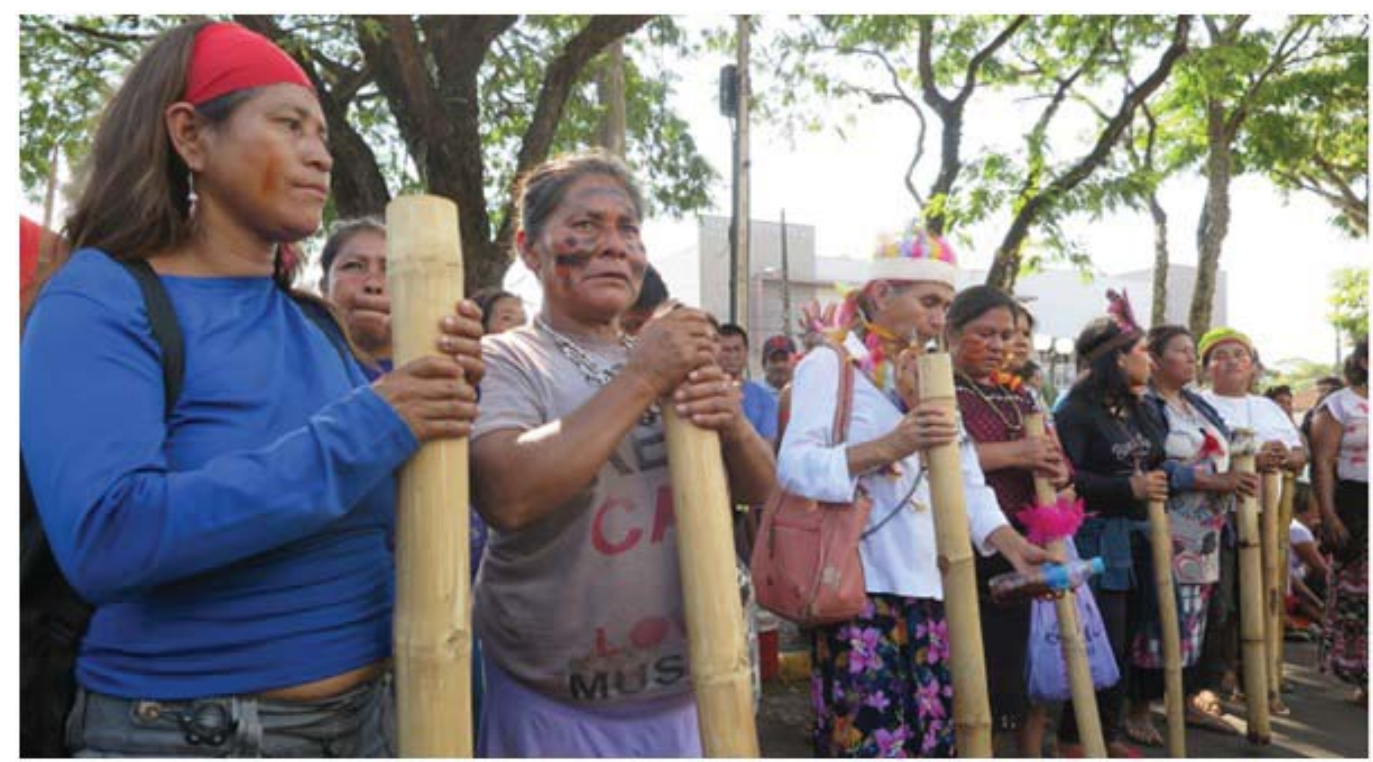

Imagem 14: Mulheres rezam em frente a prefeitura de Guaíra. Foto: Comissão Guarani Yvyrupa - CGY, 2016.

13 Guaira \& Terra Roxa - Relatório sobre Violaçôes de Direitos Humanos contra os Avá Guarani do Oeste do Paraná. https://bd.trabalhoindigenista.org.br/sites/default/files/Relatorio_Guaira\&TerraRoxa_WEB.pdf.

14 Nakamura, Rafael. "Relatório sobre Violações de Direitos Humanos contra os Avá Guarani tem ato de lançamento em Guaíra”. In: Centro de Trabalho Indigenista. https://trabalhoindigenista.org.br/relatorio-sobre-violacoes-de-direitos-humanos-contra-os-ava-guarani-tem-ato-de-lancamento-em-guaira/ 
Somando-se a estas iniciativas, no mesmo mês em que deixa seu cargo, a procuradora-geral da República, Raquel Dodge, encampa o protocolo de uma Ação Civil Originária a pedir da União, do estado do Paraná, da Funai, do Incra e da própria Itaipu Binacional os danos causados ao povo AváGuarani afetados pela Usina. ${ }^{15}$

Resultado direto da divulgação do relatório produzido pelo Grupo de Trabalho sobre Itaipu, vinculada à $6 \mathrm{a} C \mathrm{CR}$, em consonância com a pressão realizada pelo movimento indígena organizado, a ação tramita atualmente no Supremo Tribunal Federal e aguarda novos andamentos significativos. Além de trazer mais visibilidade ao caso e reforçar a contra narrativa em oposição a da UHE, a judicialização apresenta uma série de pedidos.

Dentro da ampla gama de possibilidade que nos apresenta o conceito de reparação, assim como supracitado sob a ótica da Justiça Transicional, a presente ação não demanda apenas uma indenização financeira referente aos danos morais e materiais causados, a procuradora solicita também o seguimento na procedimento demarcatório pleiteado pelos indígenas, a inclusão de disciplina no currículo escolar dos ensinos fundamental e mérito que aborde a história indígena; um pedido formal de desculpas por parte dos órgãos arguidos; juntamente com ação educativa nacional de resgate e promoção a cultura do povo Avá-Guarani como forma de combater o racismo e a discriminação.

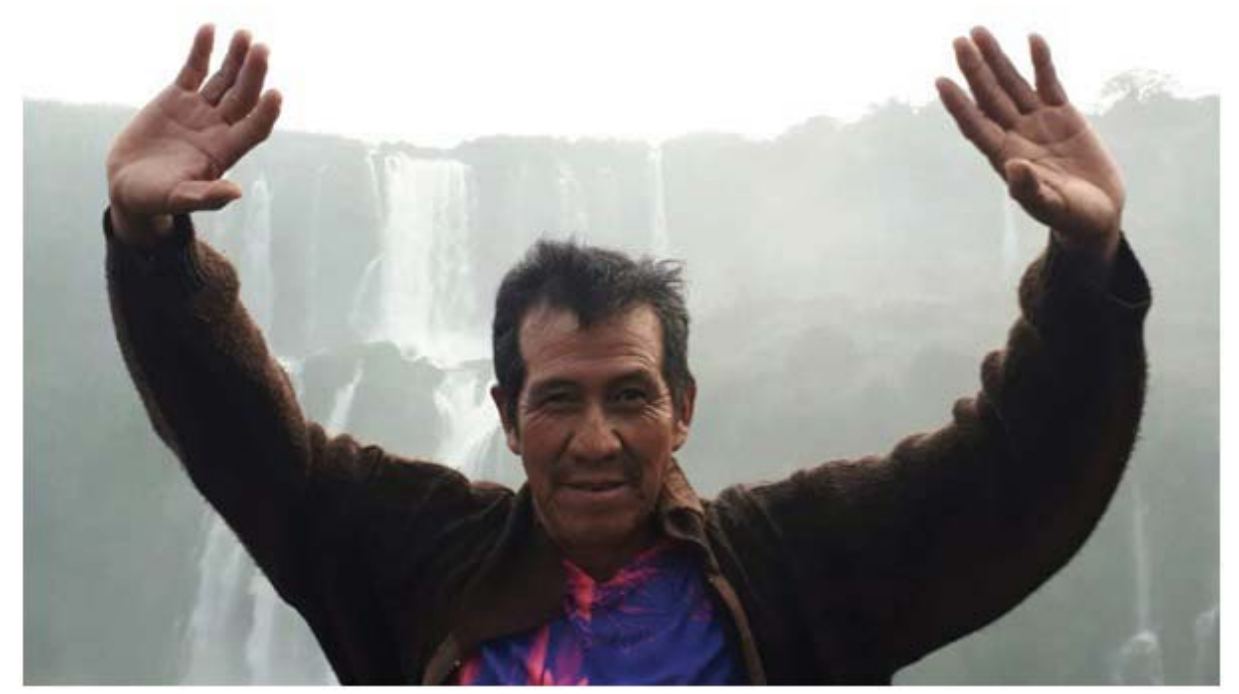

Imagem 15: Cacique Ismael Martins, da Tekoha Karumbey (PR) em visita às Cataratas do Iguaçu, em 2018. Foto: Rafael Nakamura, Centro de Trabalho Indigenista, 2018.

Júlia C. Carvalho Navarra é bacharel em Ciências Sociais (USP) e em Direito (PUC-SP) e participa da assessoria jurídica do Centro de Trabalho Indigenista (CTI) e da Comissão Guarani Yvyrup.

15 "PGR pede condenação de responsáveis por violações de direitos dos Avá-Guarani na construção da Usina de Itaipu"http://www. mpf.mp.br/pgr/noticias-pgr/pgr-pede-condenacao-de-responsaveis-por-violacoes-de-direitos-dos-ava-guarani-na-construcao-da-usina-de-itaipu. 


\section{REFERÊNCIAS BIBLIOGRÁFICAS}

ALCÂNTARA, Gustavo K, Akira Omoto, João, Araújo, Júlio e Ramos, Luciana (orgs.). 2019. AváGuarani: a construção de Itaipu e os direitos territoriai. Brasília: ESPMU.

BRANT DE CARVALHO, Maria Lucia. (s/d). Laudo pericial para a Comissão Estadual da Verdade do Paraná - "Das terras dos índios a índios sem terras. O Estado e os Guarani do Oco’y: violência, silêncio e luta”.

COMISSÃO ESTADUAL DA VERDADE TERESA URBAN. 2017. Relatório da Comissão Estadual da Verdade do Paraná/Comissão Estadual da Verdade Teresa Urban - São Paulo: TikiBooks.

COMISSÃO GUARANI YVYRUPA - Paraná. 2017. Guaíra \& Terra Roxa. Relatório sobre Violações de Direitos Humanos contra os Avá Guarani do Oeste do Paraná. Curitiba - PR.

LINI, Priscila. "Entrevista com Bartomeu Meliá". In: Mamed, Daniele; Caleiro, Manuel Munhoz e Bergold, Raul Cézar (orgs.). 2016. Os Avá-Guarani no oeste do Paraná: (Re) Existência em Tekoha Guasu Guavira. Curitiba: Letra da Lei. pp. 35-43.

MONTEIRO, John Manuel. 1994. Negros da Terra. Índios e bandeirantes nas origens de São Paulo. São Paulo: Cia. das Letras.

MAMED, Daniele; CALEIRO, Manuel Munhoz e BERGOLD, Raul Cézar (orgs.). 2016. Os AváGuarani no oeste do Paraná: (Re) Existência em Tekoha Guasu Guavira. Curitiba: Letra da Lei.

MOTA, Lúcio Tadeu. 2017. "A invasão dos territórios do povo Xetá na Serra dos Dourados/PR em meados do século XX”. Diálogos. Revista do Departamento de História e do Programa de PósGraduação em História, 21(3): 4-25.

\section{Documentos e legislações}

ITAIPU BINACIONAL, Memorando interno I/JD.RJ/0052/87. Rio de Janeiro, abril de 1987.

CNV, Cap. Indígena. pp.206

Relatório Figueiredo. 30 Volumes. Disponível em Acervo online do Museu do Índio.

CP, Resolução no 13, de 03 de dezembro de 2015

LEI 17362 - 27 de Novembro de 2012 - Comissão Estadual da Verdade do Estado do Paraná.

DOU n ${ }^{\circ}$ 50, terça-feira, 14 de março de 2017 - Exoneração

\section{Notícias e reportagens}

AUDI, Amanda. "Fotos Inéditas: Funcionários de Itaipu Comemoram Incêndio em Casas Indígenas". 12 de junho de 2018, 2h00. In: The Intercepto Brasil. Acesso em 17 de setembro de 2019.<https://theintercept.com/2018/06/12/fotos-funcionarios-itaipu-incendio-indigenas/>

HARARI, Isabel. "Ecos de Itaipu” da jornalista Isabel Harari. In: revista A Pública. Acesso 26/04/2019 <https://apublica.org/2015/03/os-ecos-de-itaipu/>

"PGR pede condenação de responsáveis por violações de direitos dos Avá-Guarani na construção da Usina de Itaipu" in. Procuradoria-Geral da República. Acesso em 17 de setembro de 2019. <http:// www.mpf.mp.br/pgr/noticias-pgr/pgr-pede-condenacao-de-responsaveis-por-violacoes-de-direitosdos-ava-guarani-na-construcao-da-usina-de-itaipu> 
MAPA GUARANI DIGITAL. Centro de Trabalho Indigenista. Acesso em 17 de setembro de 2019 <https://guarani.map.as/\#!/>

NAKAMURA, Rafael. "Relatório sobre Violações de Direitos Humanos contra os Avá Guarani tem ato de lançamento em Guaíra”. In: Centro de Trabalho Indigenista. Acesso em 17 de setembro de 2019. <https://trabalhoindigenista.org.br/relatorio-sobre-violacoes-de-direitos-humanos-contra-osava-guarani-tem-ato-de-lancamento-em-guaira/> 


\section{CASO AVÁ - GUARANI E A UHE ITAIPU BINACIONAL SOB OS OLHARES DA JUSTIÇA DE TRANSIÇÃo}

Resumo: Sob a hermenêutica da Justiça de Transição e da avaliação de meios de reparação não meramente pecuniários e punitivistas, o presente artigo versa a respeito das graves violações de Direitos Humanos sofridas pelo povo Avá-Guarani, especificamente na região Oeste do Paraná, zona de tríplice fronteira entre Paraná, Mato Grosso do Sul e Paraguai. Após uma brevíssima contextualização da localidade, dos atores e do cenário político a ditar as diretrizes das violações cometidas contras o povo Guarani na região, o artigo dá especial atenção ao caso de violências empreendidas no processo de implementação da Usina Hidrelétrica de Itaipu Binacional

Palavras-chave: Avá-Guarani; Oeste do Paraná; Comissão Nacional da Verdade; Violações de Direitos Humanos; Itaipu Binacional; Impactos de hidrelétricas; Direito indígena; Ditadura militar no Brasil.

\section{AVÁ-GUARANI CASE AND ITAIPU BINACIONAL UNDER THE EYES OF THE TRAN- SITIONAL JUSTICE}

Abstract: Under the hermeneutics of Transitional Justice and the evaluation of non-pecuniary and punitive reparations, this article deals with the serious violations of Human Rights suffered by the Avá-Guarani people, specifically in the western region of Paraná, a triple border area. between Paraná, Mato Grosso do Sul and Paraguay. After a brief contextualization of the locality, the actors and the political scenario dictating the guidelines of violations committed against the Guarani people in the region, the article gives special attention to the case of violence committed in the process of implementing the Itaipu Binacional Hydroelectric Power Plant.

Keywords: Avá-Guarani; Western Paraná; National Truth Commission; Human Rights Violations; Itaipu Binacional; Hydroelectric Impacts; Indigenous Law; Military Dictatorship.

RECEBIDO: $21 / 10 / 2019$

APROVADO: $31 / 01 / 2020$ 